(37) 式は $\varepsilon_{0}$ に関する積分方程式であるが $\sigma_{n}$ を與八れてば数 倬計算にて $\varepsilon_{0}$ のににもなふ変化を求める事が出来る。 若干の $\sigma_{n}$ に対して $\varepsilon_{0}$ の $n$ にともなふ变化を求めた結果 を第 20 図に示す。

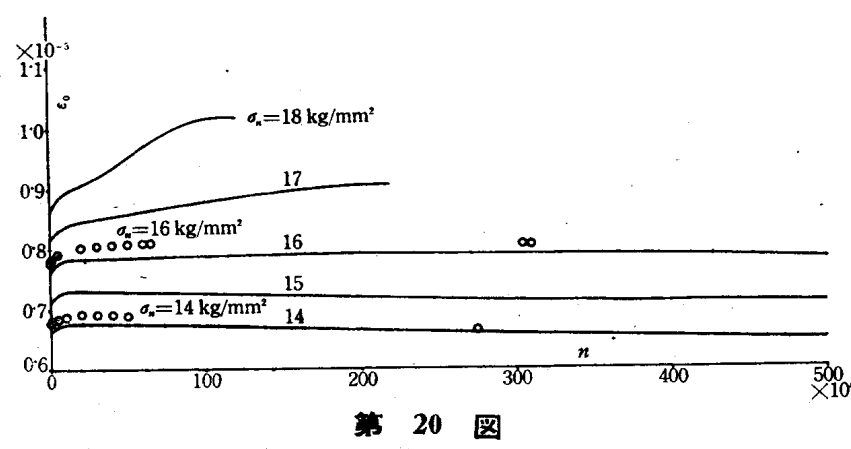

第 20 図の結果は第 9 図に示す第 2 節の実驗結果と傾向 は或程度一致するが数值は非常に離れてるる。これは $\varepsilon_{0}-n$ 曲線は $\sigma_{n}$ が少しく变ると著しく变るものであるから、第 2 節の実驗に用ひた試料と（33）式を導いた第 4 節の実驗に用 ひた試料が同一と称せられてはるるが、異なる丸棒から取つ たものであるので多少の材質の相違があり、このために差遗 を生じたものと思はれる。そこで第 4 節の実驗に用ひた試 驗片が 2 筒残つてるたのでこれで荷重即ち $\sigma_{n}$ を一定とし た試驗を行つた。第 20 図の点はこの測定結果を示す、大体 計算と一致する。
6. 結
論

低炭素瑞典鋼を用ひ均一回轉曲げ試驗を行ひ头の結果を得 た。

\title{
中間軸フランジ附根の應力 ${ }^{(2)}$
}

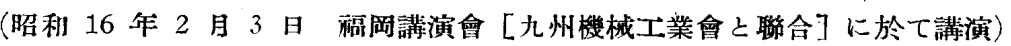

\section{1. 緒㝘}

中間軸の换りに依る剪断礁力はフランジ附根附近に於て最 大となる筈なるもこの附近より波破壊を起したる実例を聞か す且又該軸の設計には捱り振動の振動数等をも考慮しなけれ ばならない関係上必すしも最大應力のみを押へて寸法を切り 詰めることも出未策ねるから、フランジ附根に生する最大隹 力を確かめることは実際問題としては一見必すしも急を要し ない研究のやうにも感ぜられるが、大型中間軸にありては鍛 造方法の関係上フランジ部附近に材質上の弱点を生じ易く、 斯る場合に於てその弱点が使用上支障なきや否やを判断する ためにはその附近の雇力狀態を明確にして置く必要がある。 殊に第 1 図に示す如く軸端中心部に往々にして生する材料疵

(1) Stresses at the corner of the flange in the intermidiate shaft. (2) Tukumo UNo, Associate Member. Nagasaki Shipyard, Fngine Works. Mitubisi Heavy Industries Co., Ltd. 三菱重工業侖社長㥓造船所。

第 7 枩 第 28 号 (第 1 部)]
第 1 に Fry 上の氖楽の如き試楽により檢出される部部分 に就て

（1）軸方向の繰返歪振偪を一定に仿一時は試驗片內の一 点はその点の受ける繰返奀振幅、繰返数が $S-N$ 曲線に類 似する限界線を越えた時に疲部分となる。

（2）この事はあら点の波部分の発生がその点のみの繰返 應力の条件で定る事を意味する。これは繰返霍振幅が一定の 時に限ら尕、文疲部分の発生に限ら声繰返應力に上る一般の 材質の変化に就ても成立すると考へられる。

第 2 に繰返應力によりこの繰返應力と等しいもしくはこ れ以下の應力に対する應力と歪の関係が相當大なる変化をな す事を知りこれに就て

（1）軸方向の外周阷振幅 $\varepsilon_{0}$ を一定に保つ時に、 $\varepsilon_{0}$ ，繰返 数 $n$ に上る荷重 $I I$ と外周歪に比例する量 $\Delta$ との関係の 変化を表はす実驗式を求めた。

(2) これより一定の軸方向繰返歪振幅 $\varepsilon$ を受ける点の一 種の平均應力 $\bar{S}$ と歪 $\epsilon$ の関係の $\varepsilon, n$ による変化の実驗 式を導いた。

（3）上の結果究用ひ一つの仮定の下に荷重を一定とした 時の外周歪 $\varepsilon_{0}$ の繰返数にともなふ変化を計算して実驗結果 と比較した。

この実驗は大阪帝国大学機械工学呚室の南大路謙一教授、 故高林順三助教授の御指導の下に行つたもので両先生並に歪 模様の檢出、熱処理等に就て種々御教示にあつかつた航空学 教空の兒玉元一助教授、精密工学教室の上田太郎敎授、京都 帝国大学機械工学教室の西原利夫教授、河本實助教授の諸先 生に心からなる感謝を捧げる次第である。

(昭利 16 年 4 月 18 日受付)

\section{准員字野九十九螘}

を削除して凹痕を残したるま〉使用するが如き場合には、さ れがために中間軸フランジ部の强度が何の程度に弱められる かを明らか比した上でなければ安んじて探否を決定する事が 出来ない。大型中間軸はこれを廃却すると否とは工事上影響

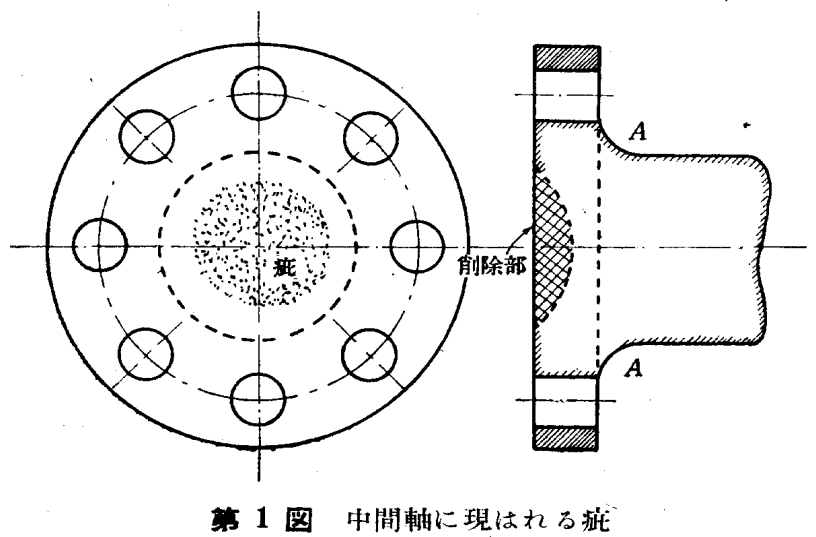


する所甚だ大なる故、使用上差支なきや否やの限界を明らか

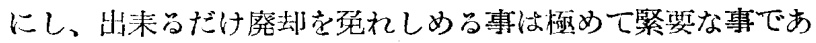
る。本報告に゙當所に於て普通に用ひられるす法比の中間軸に 就て電分的模型実驗に依てフランジ附根半径及び中空部直径 の最大應力に及方影響を明らかにし、更に軸端中心部に種々 の形狀の证削除凹みを與へた場合の最大隹力の增加を容易に 推定し得るが如き図瑟㞗めたものである。

\section{2. 應力状態の考察}

さて中間蟿が㹉り受ける時の焦力狀態に就て考へるに、 第 2 図つ如く捱りモーメントは軸本体よりフランジ仗び数本

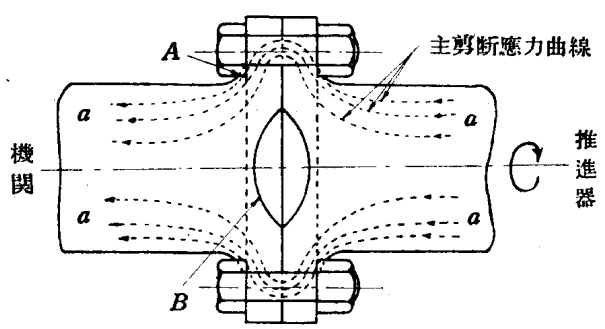

第 2 図主㮍断隼力曲線想像図

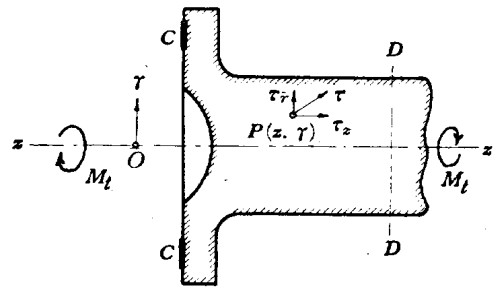

苐 3 図 應力狀㑷
を満足し、且任意の点 $P(z, r)$ の主剪断隹力 $\tau$ 前飞 $z, r$

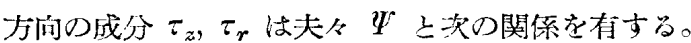

$$
\left.\begin{array}{l}
\tau=G r \frac{\partial \Psi}{\partial s}, \\
\tau_{z}=G r \frac{\partial \Psi}{\partial z}, \quad \tau_{r}=G r \frac{\partial \Psi}{\partial r} .
\end{array}\right\}
$$

而して $\Psi$ の満足すべき周辺条件は第 3 図 $C C$ 平面並にフ ランジから 充分距りたる 任意の断面 $D D$ に於て夫々 $\Psi=$ const. なることである。故に式 (1) 並に如上の周辺条件を満 足する如き $\Psi$ の分布、従て $\partial \Psi / \partial z, \partial \Psi_{/} \partial r$ 灾実驗的心求 め得れば、剪断應力の做は直ちに(2) に依て計算することが
第 4 図実驗裝惪格図
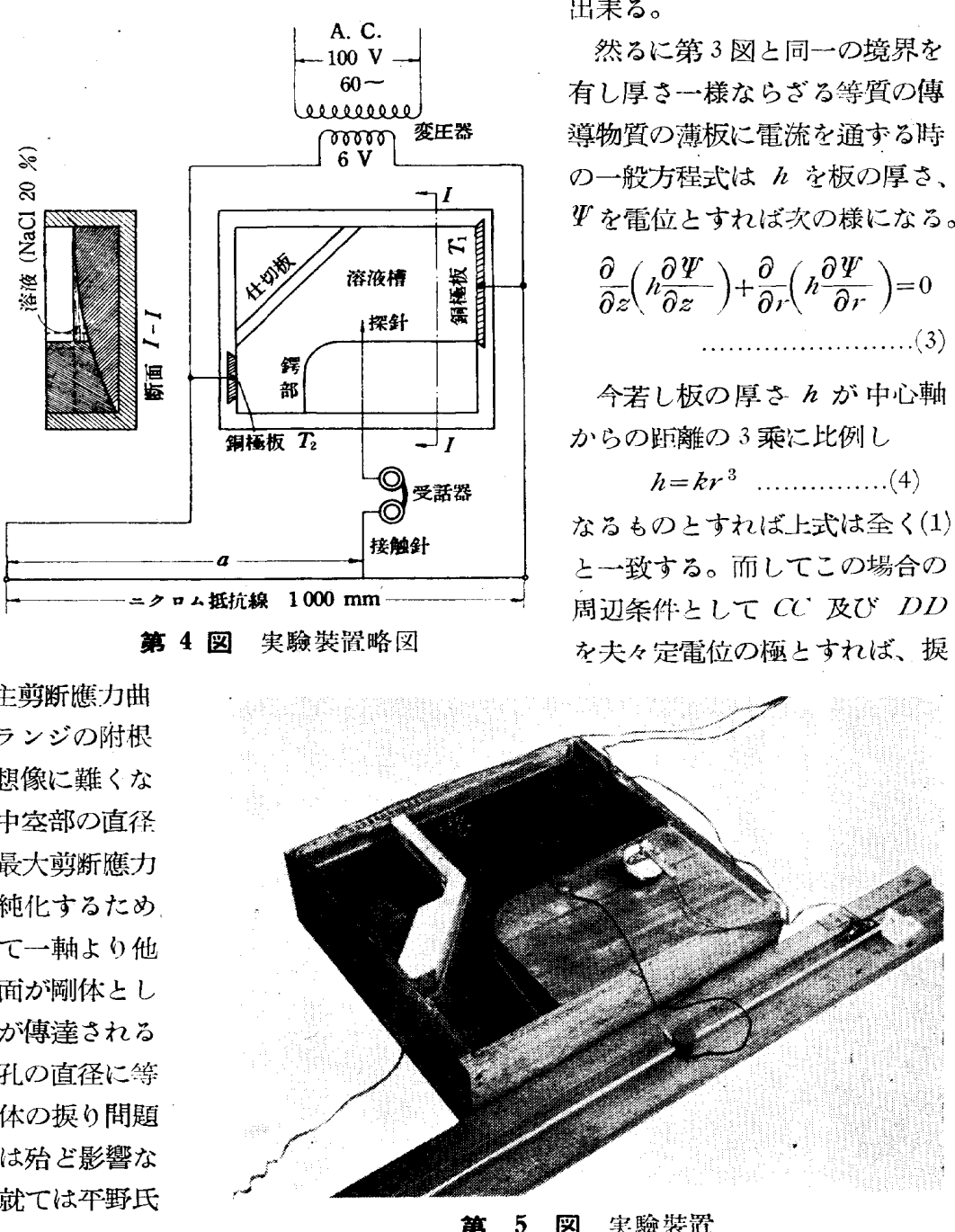

の連結用ボルトを経てとつ軸に傳へられる故、主剪断應力曲 線は大体に於て同図 $a a$ の如き分布を取り、フランジの附根 の隅肉部 $A$ 点附近に最大潐力を発生方る事は想像に難くな い。而して問題の焦点はフランジ附根の牛径、中空部の直栙 㕛は例除部の山み $B$ の形狀等に依て $A$ 点の最大剪断應力 が如何に変化するかに存する紊以て、問題を單純化するため に㹉りモーメントが数本の連結用ボルトを介して一軸より他

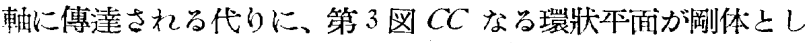
て回轉せしめられることに依て㨝りモーメントが傅達される ものと仮定しょう。但し中㠙 $C C$ の幅はボルト孔の直径に等 しいものとする。斯く俅定すれば本問題は回轉体の捱り問題 に留する事が出来、而も本仮定に問題つ焦点には殆ど影響な きことは想像に難からざる所である。合これに就ては平野氏 の文献 ${ }^{(3)}$ が参考沈なっ。

\section{3. 電氝的模型実驗の原理}

一般に回轉体即ち中心軸の風りに対称なる形を有する物体 の掟り問題は電氝的類推法に依て実驗的心解決する事が出来 る。今その原理党筧明すると、先づ座標軸 $(z, r)$ を第 3 図

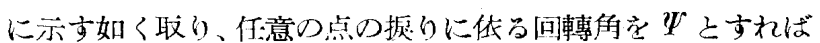
$\Psi$ は微分方程式

$$
\frac{\partial^{2} \Psi}{\partial Z^{2}}+\frac{3}{r} \frac{\partial \Psi}{\partial r}+\frac{\partial^{2} \Psi}{\partial r^{2}}=0
$$

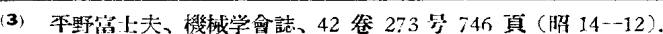

出末来る。

然るに第 3 図上同一の境界を 有し厚さ一様ならざる等質の傳 溥物質の薄板に電流を通する時 の一般方程式は $h$ æ板の厚さ、 $\Psi$ を電位とすれば次の様になる。

$$
\frac{\partial}{\partial z}\left(h \frac{\partial \Psi}{\partial z}\right)+\frac{\partial}{\partial r}\left(h \frac{\partial \Psi}{\partial r}\right)=0
$$

今若し板の厚さ $h$ が中心軸 からの距離の 3 乘に比例し

$$
h=k r^{3}
$$
と一致する。而してこの場合の 周辺案件こして $C C^{*}$ 及び $D D$ 灰夫々定電位の極上すれば、搌
なっものとすれば上式は全く(1)

り間題におけっ周边条件々全く一致せしめらことが出来る。 斯る場合に於ては電流の流線は剪断焦力の力線上一致し、等 電位線は等振り角線之一致古る事は容易に理倠出来る。

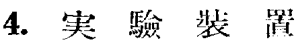

前述の原理に依り回轉体の振りの問題は電分的実驗に依て 解決する事が出未る未゙、電導物質の薄板文用ふら代りに電保 溶液槽を用ふれば一層実驗を容易ならしめる事が出未る。第 4 図及び第 5 図ば実驗装置つ略図及び写貣にして電解液槽は 軸の中心線に依て分かたれる片側だけの模型さし、深さが中 
- 心軸よりの距離の 3 乘に比例して最大深さ $80 \mathrm{~mm}$ 迄漸変す る様にし、 $\mathrm{NaCl} 20 \%$ の溶液を充たした。液槽る形造る箱の 材料法乾燥せるチーク材を用ひ、莣面に融鲜せるパラフィン

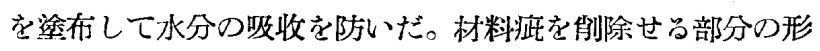
狀を形成するには図に示す如く寸法及び形狀を異にする数種 の仕切板にて浴液槽を區劃することに依て目的を澾した。及 周辺条件を満足するために銅製電極板 $T_{1}, T_{2}$ を設け、これ に6V，60↔の交流電圧を附與した。銅極板 $T_{2}$ の大きさ及 び位置は中間軸連結ボルトに相當する大きさ及び位置を取ら しめた。次に液槽內の任意の点の電位を測定するにはコール ラウシ二電橋它用ひ、抵抗線には BS＃20, 長さ $1000 \mathrm{~mm}$ のニクロム線を用ひた。

\section{5. 実驗結 果}

\section{a. 等据り角線、剪断應力及び} 周辺の隹力分布曲線 先つ第4 図 模刑に於て㾟剈除山みを有せざる 場合に就て等振り角線を実驗的に 求め、これる基礎として剪断應力 線を画きたるに第 6 図の樣になつ た。茲に等挍り角線上の○印は実 测に依て得た等電位の点にして数 字は電位差の比を示す。又相隣る 2 組の剪断應力線の間に㣣まれる 領域は略:相等しき㹉りモーメン トを真担する如く画かれてある 故、隹力線の疎密に依て直ちに應 力分布の狀態を想像する事が出未 る。本図より観るも材料应の趇は れ易き $B$ 部は應力線の密度極め て疎にして强度上重姴ならざる事 が肯かれる。この部分を削除すれ ば各應力線は幾分 $A$ の方に移動 し、 $A$ 点附近における僬力線の密 度が少しく大となっ筈であるが、 $B$ 部の㓩込が著しく大ならざる限 り $A$ 点附近の應力增加は極めて 軽微なっべきことは容易に想像さ れる。

㧖りの問題に於ては周辺に於て 剪断鷹力が最大となるものである から、周辺における剪断焦力分布 曲線は形狀の異なる種々の中間軸

\begin{tabular}{|c|c|c|c|}
\hline 主 & 华 寸 & 法 & \multirow{2}{*}{$\alpha_{\max }$} \\
\hline $2 a / d$ & $D / d$ & $D_{b} / d$ & \\
\hline 0.28 & $1 \cdot 83$ & $1 \cdot 452$ & $1 \cdot 295$ \\
\hline $0 \cdot 41$ & $1 \cdot 71$ & $1 \cdot 40$ & $1 \cdot 28$ \\
\hline
\end{tabular}

に就て各簡にこれを求め、次に示吉剪䏳應力比 $\alpha$ を以て示 した。

(周辺上の任意の点の剪䉼鷹力)

$\alpha=\frac{\text { (周辺上に於てフランジから充分距りたる点の剪断僬力) }}{}$

第 7 図、第 8 図及び第 9 図は材料疵を例除せざる中実軸、 中空軸及び截頭㨁円錐狀の㑬除凹みを有する場合に就て、斯 くの如き $\alpha$ を以て衣はした剪断應力分布 曲線を求めた実驗 結果の一例である。

b. フランジ附根部丸味半径の影㗽 前述の如く中間軸 の應力はフランジ附根部に於て最大となり、その值に最も直 接に影響するものはフランジ附根部の丸味牛洤であらから、 之の影響を考慮するため第 10 図の $2 a / d$ の比を當所に於て 普通に用ひられる範因で 2 通りに探り僬力集中係数 $\alpha_{\max }$ を 計測したるに第1装の如く $\alpha_{\max }$ の值には殆ど差堂を生じな
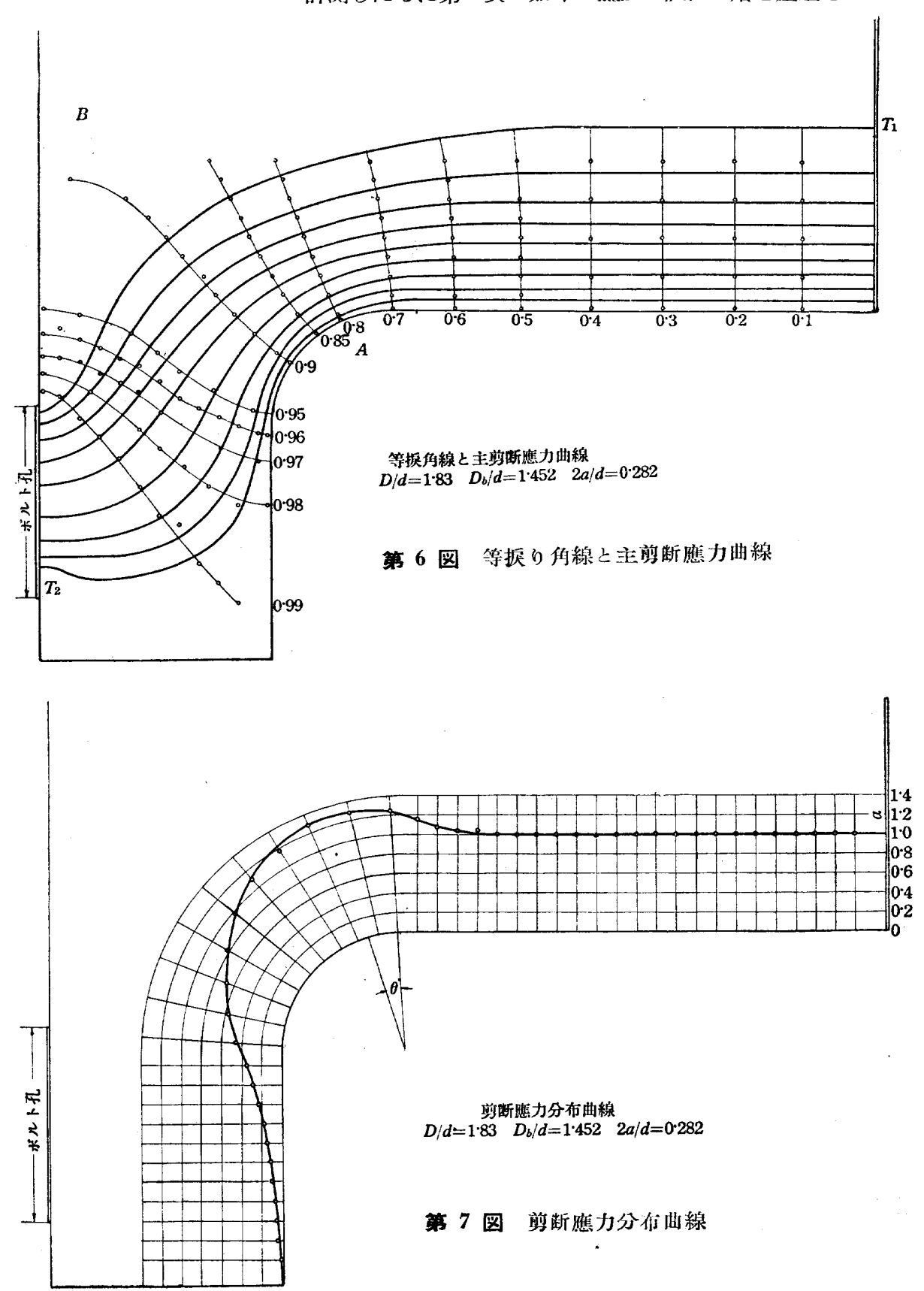

第 7 参第 28 号 (第 1 部)] 

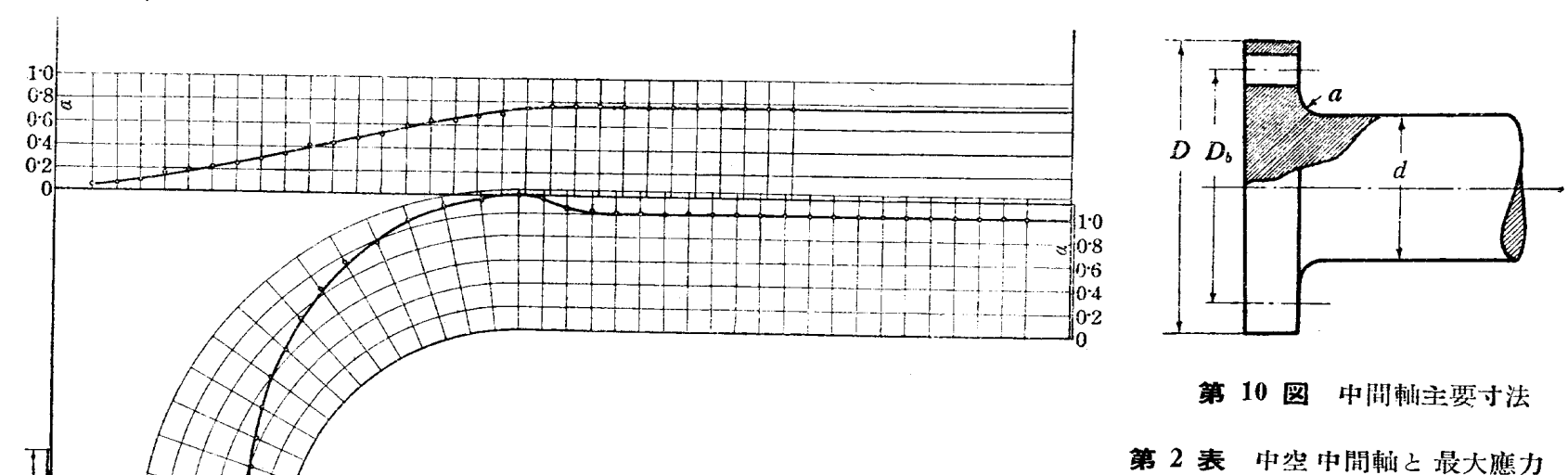

第 10 图中開檕主要寸法

第 2 表 中空中開軲之最大應力

$D^{\prime} d=1 / 71 \quad D_{h} / d=1 \cdot 4 \quad 2 a / d=0 \cdot 41$

第 8 図 剪断應力分㹥曲綜

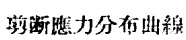

$D / d=1 \cdot 83 \quad D_{b} / d=1 \cdot 452 \quad 2 a / d=0.282$

第 9 図 剪断應力分乍曲線

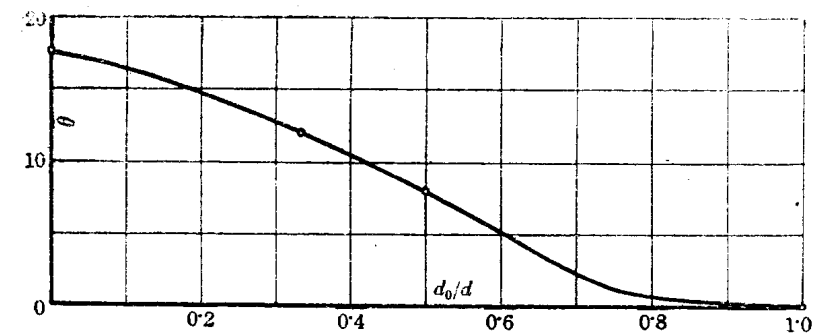

第 12 图中尘軘上最大隼力八位置

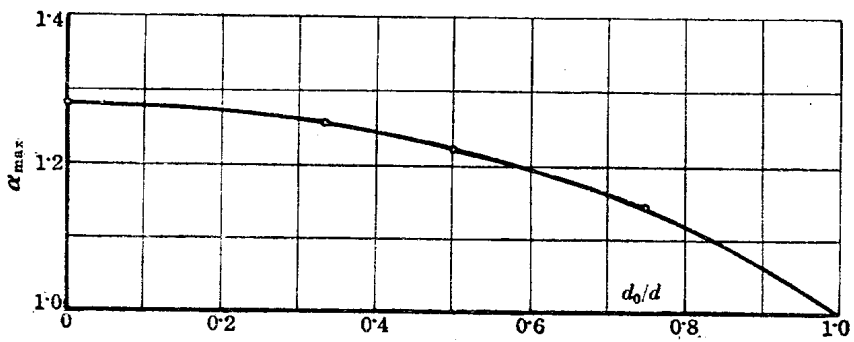

第 13 図中空軸と最大應力

\begin{tabular}{c|c|c}
\hline \hline 主要寸法 & $d_{0} / d$ & $\alpha_{\max }$ \\
\hline$D / d=1.71$ & 0 & 1.28 \\
\hline$D D_{b} / d=1.40$ & 0.333 & 1.256 \\
& 0.50 & 1.22 \\
$2 a / d=0.41$ & 0.75 & 1.145 \\
\hline
\end{tabular}

かつた。

抑も $2 a l d$ が第 1 萃に示古範国、 即ち $2 a / d=0 \cdot 28 \sim 0 \cdot 41$ よりも摆か心 小になれば $\alpha_{\max }$ は著しく增玑する 等なるま、上記範团无はこれ以上に 於ては $\alpha_{\max }$ の変化は極めて緩漫之 なる事汁第 11 図に示守如き段付軸

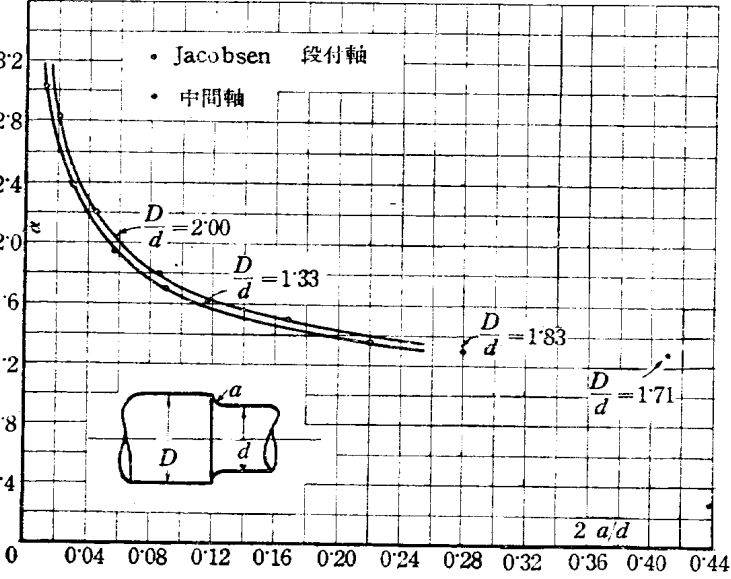

第 11 図段付軹の應力

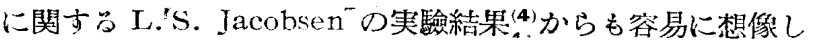

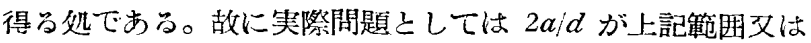
これに近い倠ならば $\alpha_{\max }$ の值に洁殆ど影響なきものと看做 すことが出来る。份 $D_{b} / d$ も幾分 $\alpha_{\max }$ に影響すう等である がその程度は僅少であっと思はれるので、ここでは実驗を省 略した。

c. 中空中間軸の應力集中係数 重量軽減のために中空 中間軸索使用方号場合には $\alpha_{\max }$ の值が多少低下゙方であら うと云ふことは実羷結果学侯つまでもなく主萑力線の分布狀 熊からも容易に推測されることである。即方第 2 产に示す如 き內径 $d_{0}$ なる中空中間軸の應力集中係数 $\alpha_{\max }$ 及びこの位

(4) S. Timoshenko, Theory of Elasticity, (1934), 283.

[昭 和 16 年 8 月 
置 $\theta$ を求め、これ等を夫々 $d_{0} / d$ に対して曲線に画けば第 12 図、第 13 図索得る。茲に $\theta$ は第7図に示す如きフラン ジ附根の丸味の起点より最大應力の集中する点迄の内弧の中 心角である。 $\alpha_{\max }$ ち $\theta$ ま $d_{0} / d$ の增加之共に次第に減少し、 $d_{0} / d \rightarrow 1$ なる極限代於ては $\theta \rightarrow 0, \alpha_{\max } \rightarrow 1$ になるるのと考へ られる。

d. 直网錐及び截頭直円錐狀削込の場合症削除の $\alpha_{\max }$ に及す影響る見るために最初に當所に於て 普通に用ひ られる寸法比の中間軸に、第 14 図 $(a) ，(b)$ に示される頂角 $90^{\circ}$ なる直円錐及び截頭直円錐狀の材料证削込を與へ、同図 に示す $h$ 及び $t$ D $H$ に対する比 $h / H, t / H$ を種々に変化 せしめて実驗を行ひ、前記周辺における剪断應力分布曲線を

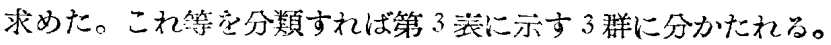
これ等の各群即ち第 I 群 $(h / H=$ 変数)、第 II 幦 $(h / H=$ $0.725, t / H=$ 変数 $) 、$ 第 III 群 $(h / H=0.8, t / H=$ 変数 $)$ に対 して夫々の変数紊橫軸に、應力集中係数 $\alpha_{\max }$ 及び應力の最

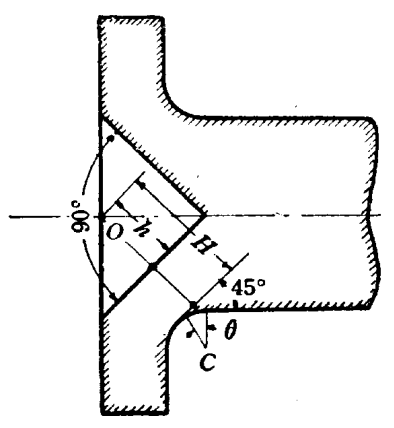

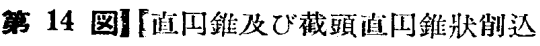

第 3 表墨㨁打錐及び截頍皅问錐狀 例达之最大㮣力

主装寸法 $D / d=1 \cdot 83, D_{b} / d=1 \cdot 45^{\prime \prime}$ ， $2 a / d=0 \cdot 282$

\begin{tabular}{|c|c|c|c|c|}
\hline 番哭 & 倒込形狀 & $h / H$ & $t / H$ & $\alpha_{\max }$ \\
\hline \multirow{6}{*}{ I } & \multirow{6}{*}{ 直问鏙 } & 0 & - & $1 \cdot 295$ \\
\hline & & 0.4 & - & $1 \cdot 31$ \\
\hline & & 0.6 & - & $1 \cdot 35$ \\
\hline & & 0.66 & - & $1 \cdot 40$ \\
\hline & & 0.725 & - & $1 \cdot 455$ \\
\hline & & 0.8 & $\cdots$ & $1 \cdot 595$ \\
\hline \multirow{4}{*}{ II } & \multirow{4}{*}{$\begin{array}{l}\text { 截頍 } \\
\text { 值錐 }\end{array}$} & \multirow{4}{*}{0.725} & $0 \cdot 168$ & $1 \cdot 34$ \\
\hline & & & $0 \cdot 316$ & $1 \cdot 395$ \\
\hline & & & 0.465 & $1 \cdot 42$ \\
\hline & & & $1 \cdot 025$ & 1.455 \\
\hline \multirow{4}{*}{ III } & \multirow{4}{*}{$\begin{array}{l}\text { 截頭 } \\
\text { 直问錐 }\end{array}$} & \multirow{4}{*}{0.8} & 0.195 & $1 \cdot 41$ \\
\hline & & & $0 \cdot 371$ & $1 \cdot 54$ \\
\hline & & & 0.550 & $1 \cdot 58$ \\
\hline & & & $1 \cdot 130$ & $1 \cdot 595$ \\
\hline
\end{tabular}

第 7 卷第 28 号 (第 1 部)]

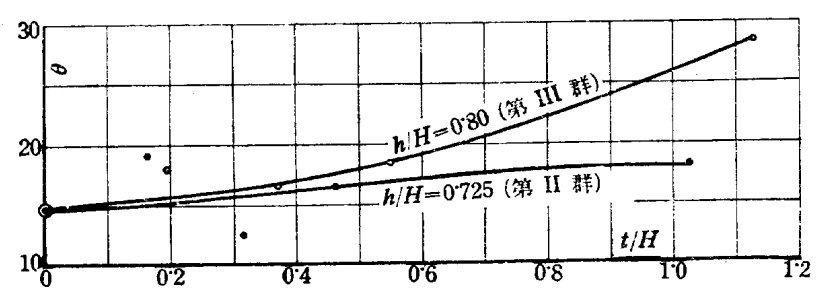

第 17 图截頭㨁四錐狀剈込を最大應力の位置

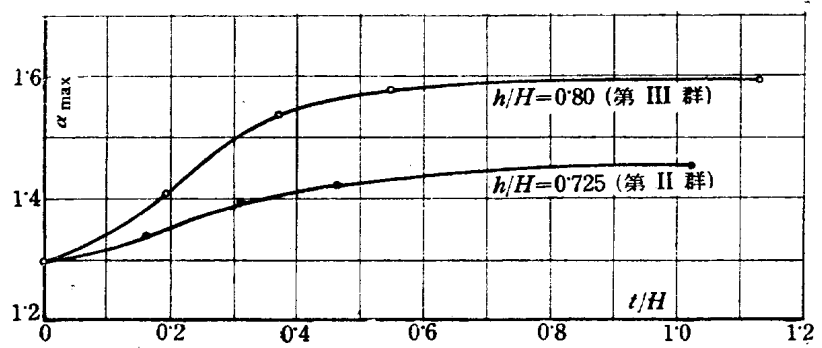

芽 18 图截頭㨁四錐狀削込と最大應力

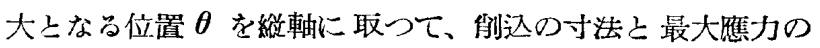
大きさ仅び位置の関係を図示すれば第 15 図乃至第 18 図を 得る。

e. 笽便に䈍力葉中係数を求める線图 以上の如く材料 疵例除部分の形狀妾頂角 $90^{\circ}$ なる直门錐又は截頭直円錐乙 する時は剈除部分の形狀は 2 筬の変数 $h / H$ 及び $t / H$ に依 て決定せられる。徉て $h / H$ 及び $t / H$ を第 19 図 $(b),(c)$ の如く維軸及じ橫軸に取えば、 任意の剈除部の形狀は座標平 湎上の一点と一ß対應する。 故に相等しき應力集中係数を 有するこれ等の点を漸結する 事に依り多数の同高線を画け ば、䬱除部分の寸法の如何に 拘ら柰その應力集中係数を容 易に求めることが出来る。

今これ等の同高線の形狀に 就て考察を進めるに $h / H$, $t / H$ は削除部の円锥がフラン ジ附根に第 19 図 (a) ○如く D点に於て接する時に最大と なり、夫々 $h / H=1, t / H=\sqrt{2}$ となる。而して $t$ が $D$ 点の 深さ $t / H=0.506$ より深くな る特は $\alpha_{\max }=\infty$ となり、こ の様に $\alpha_{\max }=\infty$ となる場合 が第 19 図 $(b)$ に於て $C B$ を 以て示してある。又 $h / H$ の 值の如何に拘らず $t / H=0$ の ときは材料㾟を削除しない場 合であつて $\alpha_{\max }=1.295$ なる から $O A$ なる直線で表はさ れる。而して本実驗で取报つ た（a）に示す如き剈除部の形 狀に対應する $(b)$ の座標平面 


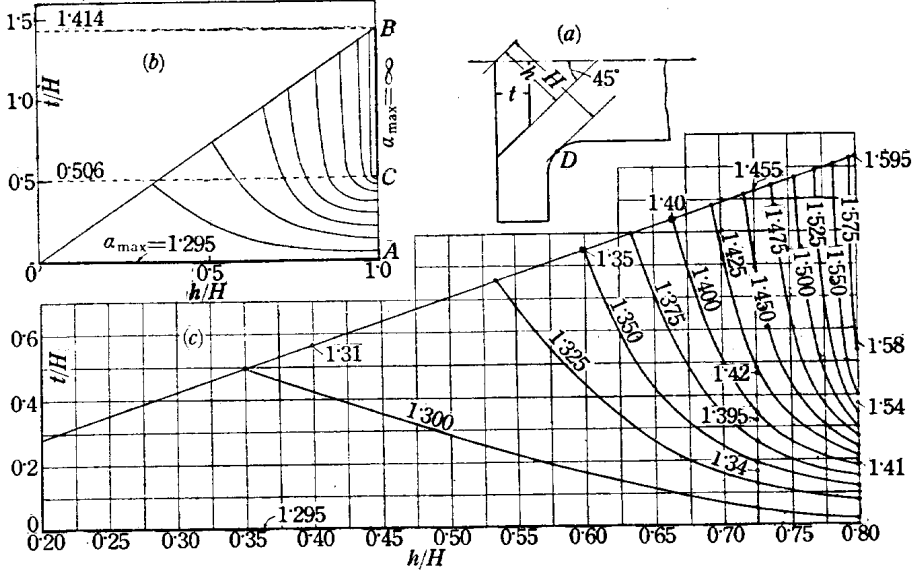

第 19 図麗使に焦力集中係数在求める線图

$t_{1}$ なる截頭㨁円錐狀㴊込 $A B C D$ の頭部 $B C$ に牛 径 $c$ なる丸味 $E M, F N$ を附し、EF の深さを $t_{2}$ とすれば血形剈込 $A E M N F D$ の雇力集中係数 $\alpha_{\max }$ は夫々深さ $t_{1}$ 及び $t_{2}$ なる截頭㨁円錐狀㓟込の

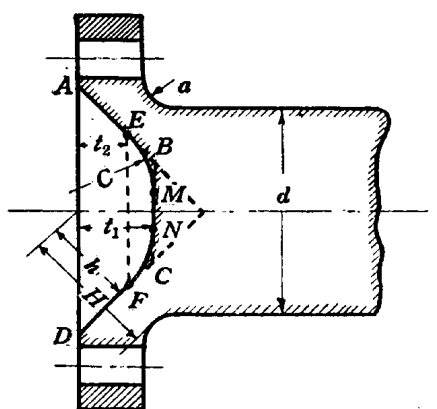

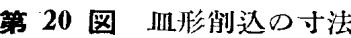

$\alpha_{1 \max }$ 及び $\alpha_{2 \max }$ の相加平均值に略 相等しいことが奏 驗に依り明らかに なつた。

$\alpha_{\max }$ $=\frac{\alpha_{1 \max }+\alpha_{2 \max }}{2}$

第 4 䒾は 2 筒の 寸法の異なら而形 削込を有する中問軸心就て 式 (5)に依ら計算值と実驗 值との比較を示す。

6. 結 論

実驗結果を裂約すれげ次 の如くである。

(1) フランジ附根の丸味

上の点は総て $\triangle O A B$ 队似あり、同高線は $O A$ と $C B$ この 間に䖝示の如く分布されることは想像に難くない。而も斯く の如き座標本面上の数点に対与っ $\alpha_{\max }$ の值は実羷仢に既に 求められてるるから、これ等の值と上述の考察と学経緯とし

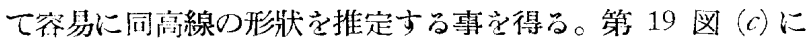
亦すものが即ちこれであつて、不図に於て○印は実驗に依て 求めた点、一印は第 16 図及び第 18 図から求めた点である。

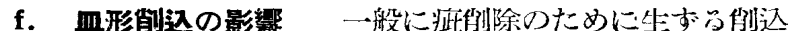
ぱ、述の如く淔円錐无は截頭直円錐形であることは少く、む

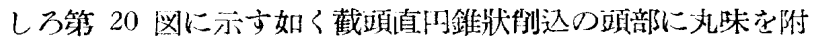
して皿形的込となした垗合が多い。即ち第 20 図に於て深さ
の影響は第 10 図 $2 a / d$ の比が $0.28 〜 0.41$ の範田では殆ど 無視することが出来、礁力集中係数は $\alpha_{\max } \cong 1 \cdot 29$ と考へて よい。

（2）中㸃中間軸の $\alpha_{\max }$ 沬第 13 図から求められる。

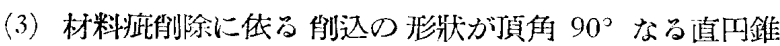

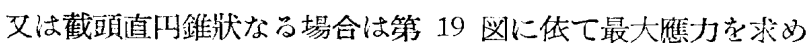
こことがけ未る。

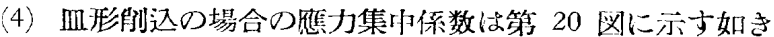

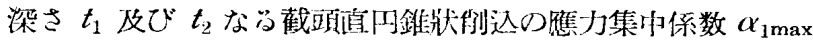
及び $\alpha_{2 \max }$ の平均们に略:相等しい。

（昭利16 年 5 月 5 日受付)

\section{一引圧疲試驗機上実 驗 例 ${ }^{(1)}$}

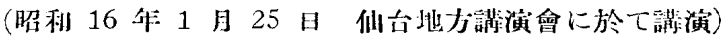

正員书原通 敏 ${ }^{(2)}$

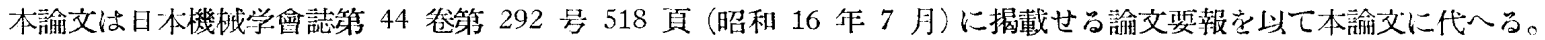

